\title{
Transatlantica
}

Revue d'études américaines. American Studies Journal

\section{Sara Blair, Harlem Crossroads}

Princeton : Princeton University Press, 2007, ISBN 0-691-13087-6

\section{Anne Crémieux}

\section{(2) OpenEdition}

Journals

Édition électronique

URL : http://journals.openedition.org/transatlantica/2383

DOI : $10.4000 /$ transatlantica.2383

ISSN : $1765-2766$

Éditeur

AFEA

Référence électronique

Anne Crémieux, «Sara Blair, Harlem Crossroads », Transatlantica [En ligne], 2 | 2007, mis en ligne le 14 mai 2008, consulté le 29 avril 2021. URL : http://journals.openedition.org/transatlantica/2383 ; DOI : https://doi.org/10.4000/transatlantica.2383

Ce document a été généré automatiquement le 29 avril 2021

\section{(c) (i)}

Transatlantica - Revue d'études américaines est mis à disposition selon les termes de la licence Creative Commons Attribution - Pas d'Utilisation Commerciale - Pas de Modification 4.0 International. 


\section{Sara Blair, Harlem Crossroads}

Princeton : Princeton University Press, 2007, ISBN 0-691-13087-6

\section{Anne Crémieux}

1 Harlem Crossroads is a detailed study of how photography has influenced black writers in the $20^{\text {th }}$ century to an extent not previously acknowledged.

2 Sara Blair traces the history of black subject photography to the Harlem riots of 1935 and 1943 that produced a " riot of images » (5) and eventually, a cultural photographic representation of New York City's most famous black neighborhood.

3 Having established how Harlem came to be a focus of particular interest to a number of photographers, Sara Blair contrasts the style of Harlem photography to the Farm Security Administration photography project and to pictures published by Life Magazine, to show the specific documentary impulse that directly inspired black writers, whether emanating from photographers outside the black community such as Aaron Siskind, or from insiders, such as Roy DeCavara. Sara Blair convincingly argues that Aaron Siskind, whose "downtown images » emerged " organically from a world " he «knew and inhabited» (25), reached in Harlem «the limits of the documentary enterprise " (47) because of the distance that existed between photographer and subject. On the contrary, DeCavara declared he was aiming for « the kind of penetrating insight and understanding of Negroes which I believe only a Negro photographer can interpret ». (51). Sara Blair considers both artists as having had a strong influence on black writers.

4 Sara Blair then looks at two major black writers who were also photographers : Richard Wright (chapter 2) and Ralph Ellison (chapter 3). Richard Wright worked with the FSA archives and documented his life and travels through still images, especially once an expatriate in France and a traveler in Africa. Sara Blair considers this information particularly important as Richard Wright's masterpiece, Native Son, has been read by Maurice Wallace as an indictment of the photographic medium controlled by Whites as a tool of oppression, implying that Wright could not himself be interested in the medium (62). Why Sara Blair believes this is implied by Wallace's reading of Richard Wright is not clear. Would Richard Wright not seek to produce documentary images of black life to counter existing images, as he did with Black Boy, one might argue ? It is a 
tendency of Sara Blair's to search for what sometimes feels like uncalled-for controversy instead of trusting her study will be well received, based on what she has to contribute. Richard Wright's interest in the work of Helen Levitt, his collaboration in the FSA and publication of Twelve Million Voices: A Folk History of the Negro in the United States (1941) and its influence on many writers and on America at large, are indeed enlightening. Sara Blair conducts a joint analysis of the pictures and words of Twelve Million Voices, showing how Richard Wright is still strongly immersed in the Communist rhetoric, only a year before he left the party in 1942. The second part of the chapter is dedicated to Richard Wright's photographs in Africa during his travels and how they function as "allegories of the failures of documentary practice» (104), as Wright reflected on his relationship to the subjects of both his photographs and writings.

5 Sara Blair considers Wright's photographic work to have greatly influenced other writers, starting with Ralph Ellison (chapter 3) who, she found out, kept in his wallet, along with a picture of his mother and another of his classmates at Tuskegee, a photo of Richard Wright holding a reflex camera (112). Ralph Ellison was a professional photographer himself, a friend of Richard Wright's, and an occasional collaborator of famous Life Magazine photographer and later first black Hollywood filmmaker Gordon Parks. Sara Blair pointedly suggests that his involvement as a photographer is central to the understanding of Invisible Man and the issue of « vision and invisibility » (114), in considering the importance of the eye / I that makes the picture, whether literary or visual. Sara Blair explores «the uses Ellison makes of photography as an analogue for the novel and of its newly analogical mode» (129) as well as the work of other photographers who influenced Ralph Ellison.

Chapter 4 concerns itself with James Baldwin and his collaboration with photographer Richard Avedon, and how they influenced each other's aesthetics, producing the photo text Nothing Personal in 1964. Besides Avedon, Sara Blair explores the work of other Jewish photographers in Harlem, including Helen Levitt and Theodore Pelatowski.

Chapter 5 looks at the covering of the "hot summers " of the 1960s, focusing on Lorraine Hansberry's publication of a photo text about the Civil Rights struggle entitled The Movement (1964), and the importance of photo-montage in Chester Himes' novel Cotton Comes to Harlem (1964). Lorraine Hansberry's The Movement includes pictures of various artists, including many of Danny Lyon whom Sara Blair argues she selected notably for his shots of women activists and his indefinite representation of femininity. As for Chester Himes' Cotton Comes to Harlem, Sara Blair focuses on the description of the photomontage juxtaposing pictures of the «Happy South » to ones of « Unhappy Africa " (page 81 of the novel) to argue that Chester Himes' attempted to «seize a second-ghetto Harlem » and portray a new vision of black life, refusing « a response to various calls-liberal, black, aesthetic, or nationalist-for identification and belonging ». (227)

Culminating in her study of Toni Morrison's Jazz (Chapter «Coda»), Sara Blair's approach of the literary through the photographic seems increasingly far-fetched. Although perfectly interesting in and of itself, her detailed study of post-WWII African American images feels only peripherally related to the literature it supposedly inspired. Sara Blair affirms in the introduction (11) that " without their engagement with photography, [the work of these writers] as we know it would have been impossible. Reading them, and other figures, through their photographic engagementwhich have remained essentially invisible within literary and cultural history-we 
arrive at an altered understanding of the literary field at mid-century, and of photography as a practice and cultural resource ». Although this is well illustrated in the case of Richard Wright and Ralph Ellison's work, it is less striking for James Baldwin, Lorraine Hansberry, Chester Himes, and Toni Morrison. These fascinating, perhaps less stylistically canonical authors are read to fit an academic argument whose frame they too obviously outgrow.

9 Sara Blair's book is nonetheless a mighty contribution to photographic and literary studies, and one can only despair in the increasingly difficult task of including images whose flagrant absence in certain chapters can only be due to excessive copyright and publishing cost. The disappointment of the missing illustrations is largely compensated by the satisfaction of the ones that did make it into the volume.

INDEX

Thèmes : Recensions

\section{AUTEUR}

ANNE CRÉMIEUX

Paris 10 Nanterre, anne.cremieux@gmail.com 